\title{
VOLUNTARY DISCLOSURE IN THE ANNUAL REPORTS OF FINANCIALLY DISTRESSED COMPANIES IN INDONESIA*
}

\author{
Wijantini
}

\begin{abstract}
This paper examines voluntary disclosure in the annual reports of financially distressed companies in Indonesia. The disclosure score range is between 3 percent and 49 percent with the mean and median score of 25 percent and 26 percent, respectively, at the onset of distress. The score is measured as the ratio of the total items disclosed to the maximum possible items score applicable to the firm. The most disclosed items are in the category of financial highlights and general corporate information whereas the three least disclosed items concern projections, liquidity, and research and development. Moreover, the results of this study reveal that the level of voluntary disclosure in the financially distressed firms is higher than that in non-financially distressed firms. There is no significant difference between the types of information disclosed by the 2 groups. The statistical tests are applied for various years. Consistent with findings in previous studies, the size of the firm appears to be a positive variable significantly affecting the disclosure level.
\end{abstract}

Keywords: disclosure; financial distress; leverage; variability of performance; size

\footnotetext{
Acknowledgement: This paper is based, in part, on my thesis completed at the University of Birmingham, UK. I am indebted to my supervisor, Dr. T.A Adedeji for his valuable comment, to my colleague Prof. Dr. Andreas Budihardjo and Prof. Ignas G.Sidik, DBA for their helpful suggestions. Remaining errors are my responsibility.
} 
Gadjah Mada International Journal of Business, September-December 2006, Vol. 8, No. 3

\section{Introduction}

In 1997, the Asian crisis hit Indonesia and caused a huge number of business failures. In addition, 117 systemic banking crises have occurred in 93 countries around the world since the late 1970s and the costs of corporate restructuring reached billions of U.S. dollars for these countries (Ramos 1999; Caprio and Klingebiel 1999).

Many studies referred to weak corporate governance as a factor which may have worsened the Indonesian economy during the crisis (Husnan 2001; Claessens et al.1999; Claessens etal. 2000; Claessens et al. 2002; Obata 2001). Disclosure is closely related to good corporate governance practice. By applying corporate transparency, information asymmetry can be reduced, hence minimizing the negative consequences of adverse selection and moral hazard problems (Utama 2003). Consequently, higher disclosure may reduce related costs in the period of financial distress. Predicated upon the aforementioned context, this study attempts to identify an important issue to examine whether troubled firms in Indonesia make voluntary disclosures.

The objectives of this paper are to explore (1) the extent to which financially distressed firms in Indonesia make voluntary disclosures by producing voluntary disclosure score, (2) the types of information or items that they disclose voluntarily in annual reports, (3) the comparison of types and level of voluntary disclosure between financially distressed and non-finan- cially distressed firms, and (4) the factors influencing the degree of voluntary disclosure in Indonesia.

This study purports to give a significant contribution to accounting knowledge by offering a comprehensive list to measure the voluntary disclosure level of financially distressed firms in Indonesia and reveals the extent of the disclosure. This paper also provides a comparison of the types of information categories disclosed by distressed and control firms. Most importantly, it demonstrates that the level of voluntary disclosure in financially distressed firms is higher than that in non-financially distressed firms. It also demonstrates that financial distress and size contribute positively to the level of firms' voluntary disclosure.

\section{Brief Literature Review}

There are some studies exploring disclosures in troubled firms (Frost 1997; Webb 2002, among others). Frost takes a sample of U.K. firms which received first time modified audit reports and were experiencing financial difficulties while Webb examines U.S. firms making voluntary disclosures in the Management's Discussion and Analysis (hereafter, MDA) section of the Annual Reports of firms with an Altman's Z-score in the bankruptcy prediction region (1.20 or lower). However, none of the disclosure studies takes a sample of Indonesian financially distressed firms. Prior studies of disclosure in Indonesia did not specify 
whether or not their samples were financially distressed (Susanto 1992; Utama 2003).

Several empirical studies have examined the voluntary disclosures in annual reports within national settings. The studies were in New Zealand (Hossain et al. 1995), Sweden (Cooke 1989), Japan (Cooke 1991), Mexico (Chow and Wong-Boren 1987), the U.K. and the U.S. (Gray et al. 1995). Using Indonesian samples, Susanto (1992) investigates the extent of corporate disclosure in annual reports of companies listed on the JSX. The conclusions of his study are as follows. First, the level of voluntary disclosure is greater for foreign-based companies than for their domestic counterparts. Second, the degree of disclosure is greater for companies listed on the JSX before the enactment of new regulations of 1987 than for those listed after this date. Third, the extent of the disclosure is not associated with the degree of foreign ownership restriction.

Utama (2003) referred to the study conducted by Gunawan (2000) which replicated the scoring method proposed by Botosan (1997). The method was developed for measuring the amount of voluntary information in the United States manufacturing samples in 1990. Consequently, the score contains not only a list of voluntary information disclosed in the annual reports of public listed companies in Indonesia but also the mandatory information, since the disclosure regulations of the countries are different. For example, a brief history of company is voluntary under U.S. regulations (Gray et al. 1995) but it is mandatory under Indonesian Capital Market Supervisory Agency regulations.

\section{Hypothesis Development}

\section{Voluntary Disclosure and Financial Distress}

Financial distress increases market uncertainty since the circumstances are often more complicated than normal condition (Opler and Titman 1994). Moreover, poor governance in Indonesian banking systems provides a natural setting for high information asymmetry between bank creditors and borrowers. Several issues suggest that most Indonesian banks are better classified as connection lending banks rather than as relationship banking. The Indonesian government regulation in October 1988 provided for a rapid domestic bank growth without adequate controlling and management systems. During this period, the banks competed to attract customers both for lending and funding and this has also impacted on banking officer turnover and quality. With inadequately qualified banking officers and a poor credit monitoring system, most banks granted loans on a collateral basis. In extreme cases, the bank did not carefully check the condition of pledged assets. Sheer competition among banks made officers decide to grant credit mostly on the basis of asset documentation of the collateral. 
Gadjah Mada International Journal of Business, September - December 2006, Vol. 8, No. 3

An extensive theoretical literature shows that collateral can mitigatemoral hazard and adverse selection problems in loan contracting (Chan and Thakor 1987; Stiglitz and Weiss 1981). However, Rajan and Winton (1995) suggest that collateral is likely to be effective only if its value can be monitored. Poor collateral monitoring systems, especially after granting loans, poor borrower's information and record systems, inferior officer quality and weak control of credit systems frequently impaired the Indonesian banking industry. In this case, collateral base lending does not give benefit in monitoring credit. Husnan (2001) states, "the deregulation of banking industry and the liberalization of capital account [in Indonesia] created a variety of new sources of financing for the corporate sector. However, the banking system proved incapable of performing its intermediation function. Because regulation was weak, banks could earn profits even when they did not gather and process information about risk."

Thus, Indonesian banks do not have good reputation in managing client information; managers of distressed firms therefore have an incentive to disclose more through various information venues in an effort to convince creditors of their chance of eventual survival. The most reliable information of future cash flows can be obtained from the managers of firms. Managers generally have better information about the firm's internal operations than do outside investors, but they may lack the incentives to make the best use of this information (Wruck 1990). At this stage, creditors and shareholders might be more aware of the quality of disclosure provided by financially distressed firms to assist them in making crucial decisions. Trueman (1986) suggests that managers should use voluntary disclosure to generate a signal about their management skills in assisting distressed firms out of financial difficulty.

Further, previous studies suggest comprehensive organizational changes, governance and structure often accompanying financial distress. These restructuring activities benefit firms which increase the level of disclosure. Healy et al. (1995) find that management changes, major business restructuring, and access to capital markets are associated with improved disclosure. In other words, being financially distressed creates value by improving the transparency of the firm. One of the possible explanations is as follows: financial distress increases conflicts among the stakeholders. The conflicts lead to complex information and inference problems for claimholders trying to value a distressed firm. In order to meet their needs, management has an incentive to disclose more. In addition, given the risk of job loss accompanying poor earnings performance in the time of financial distress, managers may try to elaborate on their performance by increasing corporate disclosure. Based on these arguments, a hypothesis can be formed. 
Wijantini-Voluntary Disclosure in the Annual Reports...

$H_{1}$ : The level of voluntary disclosure in financially distressed firms is higher than that in non-financially distressed firms.

\section{Voluntary Disclosure and Size of the Firm}

An association between disclosure and size of firm is expected in Indonesia if the following conditions apply. First, bigger size in firms is positively correlated with greater numbers of capital providers. Disclosure may increase with firm size because claimants demand greater disclosure. Second, there may be a fixed component of disclosure costs so that smaller firms may be reluctant to disclose them frequently. In addition, the cost of disseminating information may be higher for small firms because the news media are more likely to carry stories about large firms, and security analysts too are more likely to attend their meetings (O'Flaherty 1984). Lang and Lundholm (1993) support the hypothesis that the analysts' rating increases with firm size, but provide no evidence related to disclosure cost. Their study reveals that more disclosure is found in large firms than in small firms, suggesting that there may be a fixed component of disclosure cost. Accordingly, the cost per unit of size should decrease. Third, another possible explanation comes from the transaction cost hypothesis. Under this hypothesis, disclosure will increase with firm size because the incentives for private information acquisition are greater for large firms where the profit of trading on private information is higher (King et al. 1990).

The above cases suggest higher disclosure with bigger sized firms. Consistent with these arguments, a positive relationship between firm size and voluntary disclosure has been identified in many studies in U.S. setting (Firth 1979; Lang and Lundholm 1993, among others), Sweden (Cooke 1989), New Zealand (Hossain et al. 1995), Japan (Cooke 1991), China and Hong Kong (Ferguson et al. 2002) and Indonesia (Susanto 1992). Consequently, it is hypothesized that:

$\mathrm{H}_{2}$ : Voluntary disclosure is positively related to the firm size.

\section{Voluntary Disclosure and Performance Variability}

If the variability of performance measures the degree of asymmetric information, the disclosure may be associated with variability in the following ways. Higher variability of past performance indicates higher unpredictability of performance. Because the adverse selection problem increases with information asymmetry, disclosure will increase with information asymmetry. In other words, higher variability of performance leads to higher disclosure.

Some evidence suggests that disclosure may increase when perceived management information asymmetry is high. Firms appear to disclose considerable information because the information asymmetry between managers and claimants is high (Cohen 
Gadjah Mada International Journal of Business, September-December 2006, Vol. 8, No. 3

1992). Further, managerial earnings forecasts have previously been found to correct deviations between management and outsiders (Ajinkya and Gift 1984). Lang and Lundholm(1993) explain that disclosure might increase with performance variability. Higher performance variability raises firms' vulnerability to legal action; firms may thus increase disclosure to reduce it. Their study confirms that disclosure scores are higher for firms with a weaker relation between annual stock returns and earnings as the proxy for higher information asymmetry.

In terms of future uncertainties, during times of distress, firm' claimants encounter a higher probability of bankruptcies. The condition is exacerbated with high uncertainty about future performance due to the Asian crisis. Managers, expected to have more inside knowledge, may try to inform the company's claimants about the current situation in the firms and any temporary shock in the company performance. Based on the association between performance variability and voluntary disclosure among financially distressed firms in Indonesia, it is hypothesized that:

$\mathrm{H}_{3}$ : Voluntary disclosure is positively related to the variability of performance

\section{Voluntary Disclosure and Leverage}

Agency theory postulates that the separation of ownership and control causes conflict of interests between principals and agents. Jensen and
Meckling (1976) claim that agency costs are borne by firms which therefore have incentives to provide voluntary information to reduce costs. Moreover, they theoretically argue that agency costs will be higher for firms with higher debt because of the increased potential for wealth transfers from creditors to shareholders and managers. Thus, agency theory suggests that the extent of voluntary disclosure will be an increasing function of leverage.

Empirical findings of this relation are mixed. Hossain et al. (1995) identify a positive relationship between leverage and disclosure for $\mathrm{New}$ Zealand firms. Bradbury (1992) finds a significantly positive association between leverage and the extent of voluntary segment disclosure in diversified companies. However, Meek et al. (1995) report a significant negative relationship between leverage and voluntary disclosure for U.S., U.K., and continental European multinationals, although Chow and Wong-Boren (1987) and Craswell and Taylor (1992) find no relationship between leverage and disclosure in their samples.

Financially distressed firms generally have high leverage with high probability of bankruptcy. Transfer of wealth from creditors to shareholders and managers is minimized in this situation. The association between leverage and disclosure can be explained provided high leverage is associated with high conflict of interests due to greater numbers of creditors. In this case, managers have incentives to re- 
lease more information. To examine the relation between leverage and voluntary disclosure of financially distressed companies in Indonesia, we formulate the following hypothesis:

$\mathrm{H}_{4}$ : Voluntary disclosure is positively related to firm leverage.

\section{Sample Description}

\section{Identifying Financially Distressed Firms}

To be included in the sample, firms must satisfy several criteria. First, they had an interest coverage ratio between 0 and 1 for at least one year between 1997 and 2002. The interest coverage ratio is calculated from the Datastream by dividing operating profit before interest expense, income taxes, depreciation and amortization with interest charges. In this case, the interest charges (Datastream code number: 2408) represent the aggregate value of interest paid less interest received. The samples contain nonfinancial firms only, and 40 firms meet this criterion. Other reasons, for instance, incomplete data or a missing series of annual reports (one firm) and four firms in the samples going private in the year before the onset of distress, reduce the number of firms in the samples to 35 . The onset year is the year when firms for the first time have interest coverage ratio between 0 and 1 , and conduct debt restructuring.

An interest coverage ratio between 0 and 1 does not mean that firms will necessary become financially dis- tressed, that is, have difficulties in fulfilling the covenants in their debt contracts. Debt payment can be made from other sources than operating income, for firms have many options to obtain the cash needed to avoid default, including utilizing cash reserves, reducing inventory levels, extending trade creditors, drawing upon bank lines of credit, restructuring debt payments prior to default, raising equity and selling assets (Whitaker 1999). The following additional criteria should be deemed to determine the onset of distress. The auditor disclosure in notes to the financial statements must indicate that the firms are negotiating with their creditors to restructure their debts in order to avoid default. Debt restructuring is defined as an exchange of financial claims which a firm makes to avoid defaulting on its debt, including exchanges such as maturity extensions (Gilson 1990). After this screening, six firms were not supported by restructuring news and the remaining samples contain 29 financially distressed firms.

Most of the firms (16) plunged into financial distress for the first time in 1998 (55.2 percent). Seven firms renegotiated their loans with their creditors in 1997 and the remaining firms in the samples rescheduled their debts for the first time in 1999 and 2000.

\section{Disclosure Index/Score}

There are some approaches to developing a theoretical concept and operational measure of the disclosure index. Patton and Zelenka (1997) sug- 
gest the following methods. First, the index may be extended from a normative decision model against the usefulness of the disclosures. Second, it may refer to the evaluation of analysts as experts in assessing the quality of disclosure. Third, it may use certain disclosures which give a significant effect to market reaction. Finally, it may be assessed on its fulfillment of particular disclosure regulations. Similarly, Hooks et al. (2001) adopt three phases in constructing the disclosure index. First, they identify the potential disclosure items which the scoring sheet may include. Subsequently, they develop a draft index after listening to an expert panel. Eventually, they produce a final index reviewed by a panel. In other words, the index is developed through a pilot study, scoring process, and expert evaluation phases.

In order to offer a list of comprehensive indices for financially distressed firms, the following paragraph will review two chosen scoring indices produced by Botosan (1997) and Webb (2002). By examining the advantages and disadvantages of each index, the proposed index may present a more suitable and comprehensive index for Indonesian financially distressed firms.

Botosan (1997) offers an index consisting of 82 disclosure items, of which 19 are only additional information with no point score (see Appendix B). She applies various studies of information needed by investors, accountants, and businesses to choose the items included in the annual reports.
The main studies are: the study of the American Institute of Certified Public Accountants (1994) on business reporting (the Jenkin Committee report), the SRI International survey (1987) of investor information needs and the Canadian Institute of Chartered Accountants' study (1991) In detail, she identifies 63 items of information categorized into five sections: background information, summary of historical results, key nonfinancial statistics, projected information, and management discussion and analysis. She claims that her index is an unweighted measure of disclosure level, except as follows. First, the quantitative information is awarded one more point than the qualitative. The reason is that more specific information is viewed as more credible. Second, projected sales and earnings information provided by multi-segment firms is weighted by the fraction of consolidated earnings or sales being forecasted. Third, if there is inconsistency between the content of management discussion and analysis and the information found in other business reporting, only half the available points is awarded.

The Botosan samples exclude firms in reorganization under Chapter 11 of U.S. bankruptcy law, considering that it may differ from the norm. Undoubtedly, the list does not include essential disclosure for financially distressed firms, for instance, discontinued operations or disposal impact on current or future results, economic risk and climate, business and financial risk, inflation and currency transla- 
tions, debt covenants, and liquidity issues (Webb 2002). The advantage of the index is that it can be applied to firms of any size. Her study is carefully designed to avoid introducing a size bias through the following procedures. First, it scores consistently for single-segment and multi-segment firms. Second, multiple points are not awarded for multiple references to the same disclosure item. The disclosure index is purposely limited to items which any size of firm could disclose voluntarily.

Webb (2002) examines the quality of voluntary disclosures contained in the MDA section of the annual reports of firms facing financial distress. She views MDA as a credible voluntary disclosure, since the management voluntarily and considerably provides a reasonably concise narrative for the company's stakeholders, and the auditors must inspect it to ensure that it is consistent with information obtained during the audit. The contents of her index are based on the U.S.'s SEC 1989 guidelines, a practitioner checklist provided and validated by Hook and Moon (1991, 1993), and internal guidelines developed by large auditing firms. Her index consists of 46 items and comprises the general business, the results of operations, capital resources, and liquidity issues.

The Webb index has certain advantages. First, it is particularly designed for distressed firms. Second, it takes into account divestment or disposal disclosure as items to be consid- ered in calculating the index. Lasfer et al. (1996) provide us with evidence that sell-off announcements significantly affect the stock market in both financially distressed and healthy firms. In other words, the disposal disclosure is important for investors. Third, the index is thoroughly validated by the Botosan Index and AIMR Reports for 1993-94. However, the list considers only the contents of the MDA. It assumes the MDA to be sufficiently credible to represent the voluntary disclosure in the annual reports. The other shortcoming of the index is that it does not take into account the corporate strategy, for instance, the actions taken to achieve corporate objectives, and it also lacks projected employee information and competitor analysis.

In Indonesian case, the publicly listed companies generally provide low disclosure under the MDA section, whereas the Indonesian Capital Market Supervisory Agency (hereafter, CMSA) provides guidelines for MDA presentation. Herwidayatmo (2000) claims that the Indonesian regulatory framework is quite satisfactory but lacks law enforcement. This demotivates companies from following the guidelines and regulations. Alternatively, other credible sources of information can be found in the messages of the Board of Commissioners, messages of the Board of Directors, and the notes to financial statements. 
Gadjah Mada International Journal of Business, September - December 2006, Vol. 8, No. 3

After considering the advantages of these two studies, the present study provides a list of potential voluntary disclosure items by combining items and approaches from both. It mostly hinges on Webb's index (2002) but considers Botosan's procedures (1997) by designing company purposes and comprehensive items from companies of all sizes to measure disclosure quality in annual reports. Moreover, in order to compile the Indonesian voluntary disclosure item list, the combined items will be compared to the Indonesian mandatory requirements.

In detail, this study applies 112 potential items of voluntary disclosure developed by Botosan (1997) and Webb (2002). Subsequent stages are implied for measuring the voluntary disclosure in financially distressed firms. A list of voluntary disclosure items identified by Botosan (1997) and Webb (2002) is used as an initial framework. Then the items on the list are checked to see whether the identified items are mandatory. The result of the procedure is a list of voluntary disclosure items in Indonesia. Third, from the time before a company is classified as financially distressed to a year after the onset of distress, its annual reports are investigated. An unweighted scoring system is therefore applied. One point is awarded for disclosed items, zero otherwise. All scoring procedures refer to the Indonesian voluntary disclosure checklist. A voluntary disclosure score is defined as the ratio of the total items disclosed to the maximum possible items score applicable to the firm. Therefore the disclosure score (DS) is calculated as follows (Equation 1):

$$
\mathrm{DS}=\frac{\sum \text { The scores for items disclosed }}{\text { Maximum possible scores }} \text { (1) }
$$

To investigate whether being financially distressed prompts firms to increase disclosure, the study employs a few non-financially distressed firms in the same industry classification as financially distressed firms (Datastream code), fiscal year-end and exchange listing as control firms. We identify control firms by the following criteria. First, the firms in the same industry must have positive interest coverage ratio in the examined years. Subsequently, the notes to the financial statements should confirm that the firms are not in debt-restructuring programs. 13 control firms are found out of the 28 financially distressed firms. However, they represent 65 percent of the industry in the financially distressed samples.

\section{Research Design}

To test the first hypothesis $\left(\mathrm{H}_{1}\right)$, this study employs the Mann-Whitney U-test and t-test for 2 independent samples at a year before, during, and after the onset of distress, in addition to multiple regressions which apply a dummy variable representing the financial distress condition. In order to control external factors which may increase disclosure level, the study applies normal firms as control firms. We use non-financially distressed firms 
covered by Datastream (2003) which are in the same industry as some of our sample firms at the time of the onset of distress. Author uses Datastream classification because their classification scheme is well-known and widely accepted.

Ideally, this study applies all normal firms listed on the JSX as control samples, which consequently needs the total disclosure scores of all normal firms from 1996 to 2001 . However, the scoring processes for all normal firms in the sample period are lengthy to complete. Further, prior studies found a relation between industry type and the disclosure level where the extent of information may differ among industries (Cooke 1991; 1992; among others). For these reasons, this study utilizes a few normal firms as control firms that are in the same industry classification as the financially distressed firms.

The possible external factor which may affect the level of disclosure is the expected mandatory disclosure required by IMF and the World Bank. During the Asian crisis, both institutions were heavily involved in assisting the Indonesian government to relieve the distress. One of their sound suggestions was to apply good corporate governance in Indonesian companies. Accordingly, many firms anticipated this by increasing disclosure along with other good corporate governance practices, namely, hiring independent directors or commissioners and adopting good internal auditor systems before they became compul- sory. Hence, both the advent of distress and external factors may have boosted disclosure level during the sample period.

The following multiple regression Equation 2 is used to test the hypotheses stated above:

$$
\begin{aligned}
\mathrm{DS}_{\mathrm{t}}= & \gamma_{0}+\gamma_{1} \text { DISTRESS }_{\mathrm{t}}+\gamma_{2} \text { LSIZE }_{\mathrm{t}}+ \\
& \gamma_{3} \operatorname{VAR}_{\mathrm{t}}+\gamma_{4} \operatorname{LEV}_{\mathrm{t}}+\varepsilon_{\mathrm{t}}
\end{aligned}
$$

$\mathrm{DS}_{\mathrm{t}}$ is disclosure score at the onset of distress year, DISTRESS $\mathrm{t}_{\mathrm{t}}$ is a dummy variable taking the value of 1 for financially distressed firms and 0 otherwise, LSIZE $_{\mathrm{t}}$ is log of total assets at the onset of the distress year, $\mathrm{VAR}_{t}$ is standard deviation of return on assets over the preceding ten years or starting from the initial public offering year to the onset of the distress year, $\mathrm{LEV}_{\mathrm{t}}$ is total debt divided by total capital at the onset of the distress year.

\section{The Validity and Reliability of the Index}

The validity of our index is measured by three approaches: content, contextual and internal validities. The proposed index is a combined index of Botosan's (1997) and Webb's (2002) indices; each of which has been thoroughly checked for validity and reliability. For instance, it claims to have content validity since Webb's index is based on authoritative literature and practitioner guidelines provided and validated by Hooks and Moon (1991, 1993) and a review of internal guidelines developed by a large auditing 
firm. It also possesses contextual validity since it is correlated significantly $(\mathrm{p}<0.05)$ with one well known measure of disclosure quality (Botosan Index). Webb randomly chooses to score her sample by using Botosan's (1997) index and compares her index score to the Botosan score. Her index shows the Pearson correlation coefficient of $0.307(p=0.046)$, Spearman Rho of $0.36(p=0.023)$ against the Botosan Index.

Botosan (1997) assesses the validity and reliability of her index in the following ways. First, she uses internal validity by examining the correlation between the score and firms' characteristics found in previous research to be related to disclosure level. She uses Lang and Lundholm (1993) as the benchmark, since it provides the most comprehensive analysis of the determinants of disclosure level to date. The result shows that, except for several of the profitability measures, all the rank order correlation statistics are significant in the same direction across their samples. In summary, her score is significantly correlated with firm size, the earnings/returns correlation, the variance of stock returns, return on equity, and abnormal returns for the previous year and the security issuance variable. In general, the results of the correlation analysis provide evidence that the Botosan Index is a valid measure of disclosure level.

In terms of reliability, the author of the Botosan Index applies rank order correlation between the components of the disclosure index, the num- ber of Wall Street Journal articles written about the firm, and the number of financial analysts following the firm. The result shows that each of the components of the disclosure index is positively correlated with each of the remaining components, the total disclosure score, and two other proxies.

In addition to the fact that the basic indices which we use to construct our index have already been checked for validity and reliability, the combined index will be assessed for validity and reliability once more in the following ways:

The internal validity is examined by producing the multivariate analysis between disclosure score and firms' characteristics in Indonesia. The regression results illustrate that the disclosure score is a valid measure. The sign of the coefficients of LSIZE and VAR are positive (Table 1 - panel A). They are consistent with those reported by Botosan in Panel B.

To check the reliability of the index, we reclassify our index categories into Utama's (Botosan's) Index. The combination of general corporate information, corporate strategy, and competitor information in our index will be classified in the background information in Utama's (Botosan's). Financial review category is matched with a summary of historical/financial results. Information about director/management, employee information, and key nonfinancial information are combined into the key nonfinancial statistics in Utama's study. Research and Development and projected information are 
Wijantini-Voluntary Disclosure in the Annual Reports...

Table 1. Comparison of Full Regression of Disclosure Score on Firm Characteristics

Panel A: Current Sample Results

\begin{tabular}{|c|c|c|c|c|}
\hline & $\begin{array}{c}+(+) \\
\text { LSIZE }\end{array}$ & $\begin{array}{c}\text { VAR } \\
(+)\end{array}$ & $\begin{array}{c}\text { LEV } \\
(+)\end{array}$ & $\begin{array}{c}\text { DISTRESS } \\
(+)\end{array}$ \\
\hline Coefficient & 0.031 & 0.135 & -0.083 & 0.074 \\
\hline t-statistic & $3.819 * * *$ & 1.386 & -1.627 & $2.543 * *$ \\
\hline Adj. R2 & $39.5 \%$ & & & \\
\hline $\mathrm{N}$ & 42 & & & \\
\hline
\end{tabular}

Panel B: Botosan Results ${ }^{\mathrm{a}}$

\begin{tabular}{|c|c|c|c|c|c|c|c|}
\hline & $\begin{array}{c}\text { MVAL } \\
(+)\end{array}$ & $\begin{array}{c}\text { CORR } \\
(-)\end{array}$ & $\begin{array}{c}\text { STDEV } \\
(+)\end{array}$ & $\begin{array}{c}\text { ROE } \\
(-)\end{array}$ & $\begin{array}{c}\text { ARET } \\
(+)\end{array}$ & $\begin{array}{c}\text { OFF } \\
(+)\end{array}$ & $\begin{array}{c}\text { INSIDE } \\
(-)\end{array}$ \\
\hline Coefficient & 0.602 & 0.069 & 0.157 & $\overline{0.061}$ & $\overline{-0.104}$ & 0.045 & -0.125 \\
\hline t-statistic & $8.43 * * *$ & 1.07 & $2.12 * *$ & 0.85 & -1.61 & 0.99 & $-1.89 *$ \\
\hline Adj. R2 & $36.9 \%$ & & & & & & \\
\hline $\mathrm{N}$ & 169 & & & & & & \\
\hline
\end{tabular}

* Statistically significant at the 10 percent level, two-tail test.

**Statistically significant at the 5 percent level, two-tail test.

*** Statistically significant at the 1 percent level, two-tail test.

The current sample size is 42 consists of 29 financially distressed and 13 non-financially distressed firms. LSIZE is the log of total assets at the onset of distress, VAR is standard deviation of return on assets over the preceding ten years or starting from the initial public offering year to the year of the distress onset, LEV is total debt divided by total capital at the onset of distress, DISTRESS is a dummy variable taking the value of 1 for financially distressed firms and 0 otherwise. MVAL is the market value of equity at the beginning of 1990; CORR is the correlation between quarterly market-adjusted stock returns and quarterly earnings computed for the five years preceding fiscal year 1990. STDEV is the standard deviation of the residuals from the market model estimation of beta computed using at least twenty-four of the sixty monthly return observations in the five-year period ending May 31, 1991. ROE is the after tax rate of return on common equity computed for fiscal year 1990, ARET is the annual market-adjusted stock return for 1990. OFF is a dummy variable set equal to one if the firm filed a debt or equity registration statement during 1990, 1991 or 1992 and zero otherwise and INSIDE is the number of shares held by officers, directors and 10 percent principal stockholders reported in the December 1990 edition of Spectrum 6, divided by the number of common shares outstanding.

${ }^{\mathrm{a}}$ Source: Botosan (1995: 45)

classified as projected information. Finally, management discussion and analysis is in the same title category. There are three categories which do not fit any Botosan classification. Ac- quisitions and Disposals, Capital Resources, Liquidity Information Categories are excluded from reclassification, since the items are mainly derived from Webb's Index (2002) and 
Table 2. Comparison Between Disclosure Score of Financially distressed Firms after Reclassifying into Botosan's Categories and Utama's (2003)

Utama (2003) applies Botosan's Index to measure the disclosure score of a sample of Indonesian publicly listed companies. The percentage score is the actual score divided by the maximum score in each category times 100 percent. $\mathrm{S}_{\text {before }}$ is the disclosure score a year before the onset of distress, $\mathrm{S}$ is the disclosure score at the onset of distress and $\mathrm{S}_{\text {after }}$ is disclosure score at a year after the onset of distress. Overall score is the average score of all categories. Value in parentheses is the rank of the category. The highest rank value [1] indicates the most disclosed category while the lowest rank value [5] shows the least disclosed category.

\begin{tabular}{|c|c|c|c|c|}
\hline \multirow[b]{2}{*}{ Description } & \multicolumn{4}{|c|}{ Actual Score / Maximum Score (\%) } \\
\hline & $\mathbf{S}_{\text {before }}$ & $\mathbf{S}$ & $\mathbf{S}_{\text {after }}$ & Utama's \\
\hline 1. Background information & $48.2[2]$ & $48[2]$ & $52.7[2]$ & $44.25[3]$ \\
\hline 2. Summary of financial performance & $92.3[1]$ & $96[1]$ & $100[1]$ & 84.9 [1] \\
\hline 3. Nonfinancial information & $19.2[4]$ & $18.9[4]$ & $22.8[4]$ & $17.7[4]$ \\
\hline 4. Projected information & $3.3[5]$ & $8.1[5]$ & $4.3[5]$ & $4.4[5]$ \\
\hline 5. Management discussion and analysis & $24.8[3]$ & $31.3[3]$ & $31.9[3]$ & $55.7[2]$ \\
\hline Overall score & 37.56 & 40.46 & 42.34 & 41.9 \\
\hline
\end{tabular}

do not fit any Botosan categories. Table 2 provides the comparisons of the score with Utama (2003)'s. They are similar in many ways. The most often disclosed information is the summary of financial performance, and the least disclosed category is the projected information. The overall scores are around 40 percent both in our score and Utama's.

\section{Results and Discussion}

In order to provide a systematic way of linking the specific research objectives and the results of the study, this below subsection is organized as follows: each subsection will initially state each specific research objective, then it will present the summary of the results, and finally, it will be discussed.

Voluntary Disclosure Level of Financially Distressed Firms in Indonesia. The first specific research objective of the study is to measure voluntary disclosure level in the annual reports of financially distressed companies in Indonesia. The study demonstrates that Indonesian financially distressed firms make voluntary disclosures in their annual reports. The disclosure score range is between three percent and 49 percent with the mean and median scores of 25 percent and 26 percent, respectively, at the onset of distress. The percentage score is calculated from the disclosure formula in Equation 1 times 100 percent. 
Wijantini-Voluntary Disclosure in the Annual Reports...

Types of Voluntary Information Disclosed by Financially Distressed and Control Firms in Indonesia. The second specific research objective of the study is to investigate the types of voluntary information which financially distressed firms in Indonesia disclose in their annual report. The most disclosed item is in the financial review category, namely, the asset turnover or sufficient information to compute asset turnover (i.e., sales and total assets). Only one firm in the samples did not disclose this information. General corporate information category is in the second most disclosed categories. The information regarding major products, segments or subsidiaries, specific details about products, specific characteristics of principal markets, and the description of facilities are in this group of voluntary items.

Competitor and employee information are both in the third rank. The competitor analysis disclosure emerges either in positive or negative signs. For instance, Charoen Pokphand revealed, "During theyear 1998, the agribusiness industry was characterized by reduced competition ...."(Charoen Pokphand Annual Report 1998, p. 5) while Modern Photo mentioned, "1998 was marked by very strong competition in the photographic products business in the domestic market. Nevertheless, in the mid of these very difficult circumstances, the company still maintained its position as the market leader" (Modern Photo Annual Report 1998: 11). Most employee information points to human resources development, such as "The company has always tried to pay attention to human resources development. Employees' welfare has also become one of the company's priorities" (Apac Annual Report 1998: 18). Corporate strategy are in the fourth rank, followed by Management Discussion and Analysis, Information about Directors/Management, Capital Resources, Acquisitions and Disposals, Non-Financial Information, Projected Information, Liquidity, and Research and Development Information.

Panels B and C reveal the categories of voluntary disclosure at the onset of distress and a year afterwards. The ranks of disclosure categories are similar to those in panel A. The three least disclosed categories are Projected Information, Liquidity, and Research and Development. This supports Utama's finding (2003) that projected information is the least disclosed item in annual reports of Indonesian publicly listed companies.

The rank values of voluntary disclosure types in control firms show similarity to those of the distressed firms. It may be pointed out that while a distressed firm may have more detailed information than does a nondistressed firm, it does not disclose different categories of information. Some disclosures are difficult for Indonesian firms to provide, such as projected information, research and development, and liquidity. In developing countries such as Indonesia, firms have many barriers to forecasting. Unavailability of industry data, incon- 
Gadjah Mada International Journal of Business, September -December 2006, Vol. 8, No. 3

sistent government policy, and other political factors are common factors in this regard. In addition, with high economic uncertainty during the crisis, most firms are unable to provide forecasts. The low score in Research and Development and Liquidity categories may reflect the unwillingness of the firm to publicize confidential information.
Voluntary Disclosure and the Tested Variables. The third specific research objective of the study is to test four hypotheses. Panel A in Table 3 presents the Mann-Whitney U- and ttests (Panel B) for two independent samples comparing the level of information between 29 financially distressed and 13 non-financially distressed firms at a year before, during,

Table 3. Comparing Voluntary Disclosure Between Financially Distressed and Non-financially Distressed Firms

DS is the sum of the total points awarded in each of the thirteen disclosure categories. DISTRESS indicates financially distressed firms while NONDISTRESS indicates non-financially distressed firms. The negative Zstatistics indicate that the rank sums are lower than their expected values. The Null Hypothesis is DS DISTRESS does not tend to be more than DS NONDISTRESS. *** Significant at the 1 percent level; ** Significant at the 5 percent level; * Significant at the 10 percent level.

Panel A: The Mann-Whitney U Tests Between 2 Groups

\begin{tabular}{|c|c|c|c|c|c|c|}
\hline Year & Group* & $\mathbf{n}$ & $\begin{array}{l}\text { Mean } \\
\text { Ranks }\end{array}$ & $\begin{array}{c}\text { Sum of Ranks } \\
\text { Rank }\end{array}$ & $\mathbf{Z}$ & $\begin{array}{c}\text { p-value } \\
\text { (1-tailed) }\end{array}$ \\
\hline Before & $\begin{array}{l}0 \\
1\end{array}$ & $\begin{array}{l}13 \\
29\end{array}$ & $\begin{array}{l}16.38 \\
23.79\end{array}$ & $\begin{array}{l}213 \\
690\end{array}$ & -1.812 & $0.035 * *$ \\
\hline Onset & $\begin{array}{l}0 \\
1\end{array}$ & $\begin{array}{l}12 \\
28\end{array}$ & $\begin{array}{l}12.33 \\
24.00\end{array}$ & $\begin{array}{l}148 \\
672\end{array}$ & -2.896 & $0.002 * * *$ \\
\hline After & $\begin{array}{l}0 \\
1\end{array}$ & $\begin{array}{l}29 \\
13\end{array}$ & $\begin{array}{l}10.88 \\
26.26\end{array}$ & $\begin{array}{l}141 \\
761\end{array}$ & -3.761 & $0.000 * * *$ \\
\hline
\end{tabular}

Panel B: The Two Sample t-Tests

\begin{tabular}{|c|c|c|c|c|}
\hline Year & Group* & $\mathbf{n}$ & $\mathbf{t}$ & p-value (1-tailed) \\
\hline \multirow[t]{2}{*}{ Before } & 1 & 29 & \multirow[t]{2}{*}{1.812} & \multirow[t]{2}{*}{$0.039 * *$} \\
\hline & 0 & 13 & & \\
\hline \multirow[t]{2}{*}{ Onset } & 1 & 28 & \multirow[t]{2}{*}{3.123} & \multirow[t]{2}{*}{$0.001 * * *$} \\
\hline & 0 & 12 & & \\
\hline \multirow[t]{2}{*}{ After } & 1 & 29 & \multirow[t]{2}{*}{4.584} & \multirow[t]{2}{*}{$0.000 * * *$} \\
\hline & 0 & 13 & & \\
\hline
\end{tabular}

*Grouping Variable: GROUP 1 for financially distressed firms, 0 for non-financially distressed firms. 
Wijantini-Voluntary Disclosure in the Annual Reports...

and after the onset of distress. The results present significant evidence that financially distressed firms disclose more than do non-financially distressed firms. However, the results indicate that the financially distressed firms disclose more than do the non-financially distressed firms before they become distressed. With $p$-values of test results tend to be significantly stronger, namely, at the onset of distress and a year after the onset of distress, it provides weak evidence that financial distress increases voluntary disclosure. The two sample t-tests in Panel B reveal the same results as those in the Mann-Whitney test.

Table. 4.Descriptive Statistics and Pearson [Spearman] Correlation Coefficients for Variables

Disclosure Score (DS) is the sum of the total points awarded in each of the thirteen disclosure categories. LSIZE is the log of total assets in each related year, VAR is the standard deviation of return on assets over the preceding ten years or starting from the initial public offering year for each related year, LEV is the total debt divided by total capital in each related year, DISTRESS is a dummy variable taking the value of 1 for financially distressed firms and 0 otherwise. Panel A consists of 42 firms with DS at a year before the onset of distress. Panel B consists of 40 firms with DS at the onset of distress. Panel C consists of 42 firms with DS at a year after the onset of distress. Panel $\mathrm{D}$ consists of 29 financially distressed firms only at a year before the onset of distress. Panel E consists of 28 financially distressed firms only at the onset of distress. Panel F consists of 29 financially distressed firms only at a year after the onset of distress. Spearman coefficients are in parentheses. ${ }^{* * *}$ Significant at the 1 percent level; $* *$ Significant at the 5 percent level; * Significant at the 10 percent level.

Panel A: Sample of 29 Distressed and 13 Non-distressed Firms a Year Before the Onset of Distress

\begin{tabular}{|c|c|c|c|c|c|}
\hline Item & DS & VAR & LEV & DISTRESS & LSIZE \\
\hline $\mathrm{DS}_{\text {before }}$ & $\begin{array}{r}1.000 \\
{[1.000]}\end{array}$ & & & & \\
\hline VAR & $\begin{array}{r}0.117 \\
{[-0.134]}\end{array}$ & $\begin{array}{r}1.000 \\
{[1.000]}\end{array}$ & & & \\
\hline LEV & $\begin{array}{r}0.010 \\
{[-0.086]}\end{array}$ & $\begin{array}{r}0.646^{* * * *} \\
{\left[0.278^{*}\right]}\end{array}$ & $\begin{array}{r}1.000 \\
{[1.000]}\end{array}$ & & \\
\hline DISTRESS & $\begin{array}{r}0.275^{*} \\
{\left[0.282^{*}\right]}\end{array}$ & $\begin{array}{r}0.090 \\
{[-0.117]}\end{array}$ & $\begin{array}{r}0.476^{* * *} \\
{\left[0.533^{* * *}\right]}\end{array}$ & $\begin{array}{r}1.000 \\
{[1.000]}\end{array}$ & \\
\hline LSIZE & $\begin{array}{r}0.234 \\
{\left[0.260^{*}\right]}\end{array}$ & $\begin{array}{r}-0.194 \\
{\left[-0.305^{* *}\right]}\end{array}$ & $\begin{array}{r}0.122 \\
{[0.135]}\end{array}$ & $\begin{array}{r}0.323^{* *} \\
{\left[0.308^{* *}\right]}\end{array}$ & $\begin{array}{r}1.000 \\
{[1.000]}\end{array}$ \\
\hline Mean & 0.206 & 0.053 & 0.654 & 0.690 & 19.837 \\
\hline St. Dev & 0.073 & 0.107 & 0.360 & 0.468 & 1.260 \\
\hline
\end{tabular}


Gadjah Mada International Journal of Business, September-December 2006, Vol. 8, No. 3

Panel B: Sample of 28 Financially Distressed and 12 Non-financially Distressed Firms at the Onset of Distress

\begin{tabular}{|c|c|c|c|c|c|}
\hline Item & DS & VAR & LEV & DISTRESS & LSIZE \\
\hline$\overline{\mathrm{DS}}$ & & $\begin{array}{r}1.000 \\
{[1.000]}\end{array}$ & & & \\
\hline VAR & 0.104 & $\begin{array}{r}1.000 \\
{[0.068]}\end{array}$ & {$[1.000]$} & & \\
\hline LEV & $\begin{array}{c}0.289^{*} \\
{[0.210]}\end{array}$ & $\begin{array}{r}0.198 \\
{[0.197]}\end{array}$ & $\begin{array}{r}1.000 \\
{[1.000]}\end{array}$ & & \\
\hline DISTRESS & $\begin{array}{r}0.451^{* * *} \\
{\left[0.463^{* * *}\right]}\end{array}$ & $\begin{array}{r}0.160 \\
{[0.095]}\end{array}$ & $\begin{array}{r}0.689 * * * \\
{[0.604 * * *]}\end{array}$ & $\begin{array}{r}1.000 \\
{[1.000]}\end{array}$ & \\
\hline LSIZE & $\begin{array}{r}0.545^{* * * *} \\
{[0.467 * * *]}\end{array}$ & $\begin{array}{r}-0.166 \\
{[-0.122]}\end{array}$ & $\begin{array}{r}0.446 * * * \\
{\left[0.410^{* * *}\right]}\end{array}$ & $\begin{array}{r}0.333^{* *} \\
{\left[0.335^{* *}\right]}\end{array}$ & $\begin{array}{r}1.000 \\
{[1.000]}\end{array}$ \\
\hline Mean & 0.225 & 0.076 & 0.730 & 0.700 & 20.081 \\
\hline St. Dev & 0.078 & 0.108 & 0.285 & 0.464 & 1.390 \\
\hline
\end{tabular}

Panel C: Sample of 29 Financially Distressed and 13 Non-financially Distressed Firms a Year After the Onset of Distress

\begin{tabular}{|c|c|c|c|c|c|}
\hline Item & DS & VAR & LEV & DISTRESS & LSIZE \\
\hline $\mathrm{DS}_{\text {after }}$ & $\begin{array}{r}1.000 \\
{[1.000]}\end{array}$ & & & & \\
\hline VAR & $\begin{array}{r}0.132 \\
{[0.168]}\end{array}$ & $\begin{array}{r}1.000 \\
{[1.000]}\end{array}$ & & & \\
\hline LEV & $\begin{array}{r}0.416 * * * \\
{[0.513 * * *]}\end{array}$ & $\begin{array}{r}0.316^{* *} \\
{\left[0.423^{* * *}\right]}\end{array}$ & $\begin{array}{r}1.000 \\
{[1.000]}\end{array}$ & & \\
\hline DISTRESS & $\begin{array}{r}0.586^{* * *} \\
{\left[0.587^{* * *}\right]}\end{array}$ & $\begin{array}{r}0.204 \\
{[0.303 * *]}\end{array}$ & $\begin{array}{r}0.573^{* * *} \\
{\left[0.618^{* * *}\right]}\end{array}$ & $\begin{array}{r}1.000 \\
{[1.000]}\end{array}$ & \\
\hline LSIZE & $\begin{array}{c}0.452^{* * *} \\
{[0.394 * *]}\end{array}$ & $\begin{array}{r}-0.210 \\
{[-0.144]}\end{array}$ & $\begin{array}{r}0.428^{* * *} \\
{\left[0.436^{* * *}\right]}\end{array}$ & $\begin{array}{r}0.325^{* *} \\
{\left[0.337^{* *}\right]}\end{array}$ & $\begin{array}{r}1.000 \\
{[1.000]}\end{array}$ \\
\hline Mean & 0.219 & 0.090 & 0.726 & 0.690 & 20.190 \\
\hline St. Dev & 0.069 & 0.089 & 0.402 & 0.468 & 1.379 \\
\hline
\end{tabular}

\section{Correlation Analyses}

Table 4 provides Pearson and Spearman Rho correlation coefficients between variables included in the regression analysis discussed below. All panels present Pearson and Spearman
Rho correlation for variables in a year before, during, and after the onset of distress. In general, the correlation between disclosure score (DS) and DISTRESS is significant. The tests also reveal positive correlations between VAR and LEV, LEV and DIS- 
TRESS, LSIZE and DISTRESS. The last rows present the means and standard deviations of the variables at various years.

\section{Regression Analysis}

Table 5 reports the regression of disclosure scores on firm characteristics at various times. Regression (1) applies samples consisting of financially distressed and control firms a year before the onset of distress. Regression (1) reveals that financially distressed firms disclose more than do non-financially distressed firms $(p=0.0356)$. It is consistent with MannWhitney and t-test results. Accordingly, the result supports the first hypothesis. The regression also presents evidence that VAR is a significant factor affecting the level of disclosure score with p-value of 0.0366 . It is consistent with the third hypothesis.

Regression (2) presents evidence that financially distressed firms disclose more than do non-financially distressed firms $(p$-value $=0.0156)$. The regression also presents consistent evidence that LSIZE is a significant factor that affects the level of disclosure score with p-value of 0.0005 . Therefore, they are consistent with the first and the second hypotheses.

Regression (3) applies samples consisting of financially distressed and control firms a year after the onset of distress. Regression (3) also reveals that financially distressed firms disclose more than do non-financially distressed firms $(p=0.0036)$. The result supports the first hypothesis and is consistent with Mann-Whitney and ttest results. The regression also presents evidence that LSIZE is a positive factor that affects the level of disclosure score with p-value of 0.0307 .

The results of regression (1), (2) and (3) show significant positive signs of the DISTRESS coefficient which indicates that financially distressed firms may disclose more than may non-financially distressed firms. We conclude that the multivariate analysis also gives evidence that the level of voluntary disclosure in financially distressed firms in higher than that in nonfinancially distressed firms. However, they do not provide evidence that the advent of financial distress triggers financially distressed firms to disclose more.

Regression (4), (5 and (6) apply the samples of financially distressed firms in a year before, during, and after the onset of distress. Again, they show that the size of the firm is a significant variable relating to disclosure level.

Most of the regression estimates show that the size of the firm is a significant variable relating to the disclosure level. Positive signs indicate that greater size is associated with higher disclosure level. Further, the coefficient of performance variability (VAR) is positive as expected, but not economically significant in all regressions. These results provide no significant support for the adverse selection argument. 
Gadjah Mada International Journal of Business, September-December 2006, Vol. 8, No. 3

\section{Table 5. Regressions of Disclosure Score on Firm Characteristics}

The table presents the results of linear regressions of Disclosure Score (DS) on firm characteristics. LSIZE is the log of total assets, VAR is the standard deviation of return on assets over the preceding ten years or starting from the initial public offering year until estimated year, LEV is total debt divided by total capital and DISTRESS is a dummy variable taking the value of 1 for financially distressed firms and 0 otherwise.. The sample size for Regression (1) is 42, consists of 29 financially distressed and 13 non-distressed control firms at a year before the onset of distress, for Regression (2) is 40 , consists of 28 financially distressed and 12 non-distressed control firms at the onset of distress, for Regressions (3) is 42, consist of 29 financially distressed and 13 non-distressed control firms at a year after the onset of distress. Regression (4) consists of 29 financially distressed firms at a year before the onset of distress. Regression (5) consists of 28 financially distressed firms at the onset of distress. Regression (6) consists of 29 financially distressed firms at a year after the onset of distress. p-values are in parentheses.

\begin{tabular}{|c|c|c|c|c|c|c|}
\hline & (1) & (2) & (3) & (4) & (5) & (6) \\
\hline Intercept & $\begin{array}{r}-0.083 \\
{[0.6434]}\end{array}$ & $\begin{array}{c}-0.413^{* *} \\
{[0.0123]}\end{array}$ & $\begin{array}{r}-0.173 \\
{[0.2426]}\end{array}$ & $\begin{array}{r}0.065 \\
{[0.7913]}\end{array}$ & $\begin{array}{r}-0.247 \\
{[0.2310]}\end{array}$ & $\begin{array}{r}-0.163 \\
{[0.2426]}\end{array}$ \\
\hline $\operatorname{LSIZE}(+)$ & $\begin{array}{r}0.015 \\
{[0.1172]}\end{array}$ & $\begin{array}{c}0.031^{* * *} \\
{[0.0005]}\end{array}$ & $\begin{array}{c}0.016^{* *} \\
{[0.0307]}\end{array}$ & $\begin{array}{r}0.010 \\
{[0.4116]}\end{array}$ & $\begin{array}{r}0.022 * \\
{[0.0531]}\end{array}$ & $\begin{array}{r}0.018^{* *} \\
{[0.0172]}\end{array}$ \\
\hline $\operatorname{VAR}(+)$ & $\begin{array}{c}0.313^{* *} \\
{[0.0366]}\end{array}$ & $\begin{array}{r}0.135 \\
{[0.1744]}\end{array}$ & $\begin{array}{r}0.092 \\
{[0.4107]}\end{array}$ & $\begin{array}{r}0.316 \\
{[0.1464]}\end{array}$ & $\begin{array}{r}0.106 \\
{[0.3482]}\end{array}$ & $\begin{array}{r}0.185^{*} \\
{[0.0814]}\end{array}$ \\
\hline $\operatorname{LEV}(+)$ & $\begin{array}{c}-0.102 * * \\
{[0.0368]}\end{array}$ & $\begin{array}{r}-0.083 \\
{[0.1126]}\end{array}$ & $\begin{array}{r}-0.006 \\
{[0.8183]}\end{array}$ & $\begin{array}{r}-0.099 \\
{[0.2631]}\end{array}$ & $\begin{array}{r}-0.028 \\
{[0.7596]}\end{array}$ & $\begin{array}{r}0.012 \\
{[0.6702]}\end{array}$ \\
\hline DISTRESS $(+)$ & $\begin{array}{c}0.061^{* *} \\
{[0.0356]}\end{array}$ & $\begin{array}{c}0.074 * * \\
{[0.0156]}\end{array}$ & $\begin{array}{c}0.069 * * * \\
{[0.0036]}\end{array}$ & & & \\
\hline Adj. $R^{2}$ & 0.14 & 0.38 & 0.38 & 0.02 & 0.16 & 0.25 \\
\hline Fratio & $\begin{array}{r}2.553^{*} \\
{[0.0551]}\end{array}$ & $\begin{array}{r}6.872 * * * \\
{[0.0003]}\end{array}$ & $\begin{array}{c}7.021 * * * \\
{[0.0003]}\end{array}$ & $\begin{array}{c}7.021 \text { *** } \\
{[0.0003]}\end{array}$ & $\begin{array}{r}2.2815 \\
{[0.1049]}\end{array}$ & $\begin{array}{r}3.6474 * * \\
{[0.0262]}\end{array}$ \\
\hline $\mathrm{AR}$ & $\begin{array}{r}1.3596 \\
{[0.2700]}\end{array}$ & $\begin{array}{c}4.8342 * * \\
{[0.0144]}\end{array}$ & $\begin{array}{r}0.110 \\
{[0.8961]}\end{array}$ & $\begin{array}{r}0.714 \\
{[0.5001]}\end{array}$ & $\begin{array}{r}2.555 \\
{[0.1005]}\end{array}$ & $\begin{array}{r}0.247 \\
{[0.7829]}\end{array}$ \\
\hline NormalityChi^2(2) & $\begin{array}{c}12.7 * * * \\
{[0.0018]}\end{array}$ & $\begin{array}{c}7.860 * * \\
{[0.0196]}\end{array}$ & $\begin{array}{r}3.457 \\
{[0.1775]}\end{array}$ & $\begin{array}{c}6.005^{* *} \\
{[0.0497]}\end{array}$ & $\begin{array}{r}4.202 \\
{[0.1223]}\end{array}$ & $\begin{array}{r}0.943 \\
{[0.6238]}\end{array}$ \\
\hline $\mathrm{Xi}^{\wedge} 2$ & $\begin{array}{r}0.373 \\
{[0.9100]}\end{array}$ & $\begin{array}{r}1.817 \\
{[0.1247]}\end{array}$ & $\begin{array}{r}0.686 \\
{[0.6827]}\end{array}$ & $\begin{array}{r}0.177 \\
{[0.9935]}\end{array}$ & $\begin{array}{r}1.472 \\
{[0.2461]}\end{array}$ & $\begin{array}{r}0.645 \\
{[0.6931]}\end{array}$ \\
\hline RESET & $\begin{array}{r}0.193 \\
{[0.6629]}\end{array}$ & $\begin{array}{r}0.169 \\
{[0.6834]}\end{array}$ & $\begin{array}{r}0.729 \\
{[0.3988]}\end{array}$ & $\begin{array}{r}0.075 \\
{[0.7862]}\end{array}$ & $\begin{array}{r}1.399 \\
{[0.2488]}\end{array}$ & $\begin{array}{r}0.350 \\
{[0.0559]}\end{array}$ \\
\hline
\end{tabular}

*** Significant at the 1 percent level; ** Significant at the 5 percent level; * Significant at the 10 percent level 
Wijantini-Voluntary Disclosure in the Annual Reports...

\section{Conclusions}

This paper investigates several issues related to voluntary disclosure by financially distressed firms in Indonesia and offers a combined index for measuring voluntary disclosure there. It is basically developed from Botosan's (1997) and Webb's (2002) indices. After comparing the index with previous studies, we show that the proposed index and score are valid and reliable. The average and median of disclosure score are 25 percent and 26 percent, respectively, at the onset of distress. The total possible scores are 77 measures of 13 different items of information in the annual reports. The most disclosed items are in the cat- egory of financial highlights and general corporate information whereas the three least disclosed items concern projections, liquidity, and research and development. Moreover, the results of this study reveal that the level of voluntary disclosure in financially distressed firms is higher than that in nonfinancially distressed firms. The MannWhitney U nonparametric test, t-test, and regression analysis are applied for various years. Consistent with findings in previous studies, the size of the firm appears to be a positive variable significantly affecting the disclosure level (Susanto 1992; Utama 2003; Firth 1979; Cooke 1989; 1991; Hossain et al. 1995; Ferguson et al. 2002, among others).

\section{References}

Ajinkya, B. B., and M. J. Gift. 1984. Corporate managers' earning forecasts and symmetrical adjustments of market expectations. Journal of Accounting Research 22 (2) (Autumn): 425-444.

BAPEPAM/CMSA (Indonesia Capital Market Supervisory Agency). Regulations.

Botosan, C. A. 1997. Disclosure level and the cost of equity capital. The Accounting Review 72 (3) (July): 323-349.

Bradbury, M. E. 1992. Voluntary disclosure of financial segment data: New Zealand evidence. Accounting and Finance 32 (1) (May): 15-26.

Caprio, G., and D. Klingebiel. 2003. Episodes of systemic and borderline financial crises. World Bank Financial Sector Policy and Strategy Group. Washington, D.C.

Chan, Y., and A. V. Thakor. 1987. Collateral and competitive equilibria with moral hazard and private information. Journal of Finance 42: 345-363.

Chow, C. W., and A. Wong-Boren. 1987. Voluntary financial disclosure by Mexican Corporations. The Accounting Review (July): 533-541.

Claessens, S., S. Djankov, J. P. H. Fan, and L. H. P. Lang. 2000. The costs of group affiliation: Evidence from East Asia. Working Paper (July). 
Claessens, S., S. Djankov., and G. Ferri. 1999. Corporate distress in East Asia: Assessing the impact of interest and exchange rate shocks. Emerging Markets Quarterly (Summer): 8 -13.

Claessens, S., J. P. H. Fan, and L. H. P. Lang. 2002. The benefits and costs of group affiliation: Evidence from East Asia. Working Paper (April).

Cohen, L. 1992. Some Biotech Firms Excel at state of the art hype. Wall Street Journal.

Cooke, T. E. 1989. Voluntary corporate disclosure by Swedish companies. Journal of International Financial Management and Accounting 1 (2): 171-195.

Cooke, T. E. 1991. An assessment of voluntary disclosure in the annual reports of Japanese corporations. International Journal of Accounting 26 (3): 174-189.

Craswell, A., and S. Taylor. 1992. Discretionary disclosure of reserves by oil and gas companies: An economic analysis. Journal of Business Finance and Accounting 19 (2): 295-308.

Ferguson, M. J., K. C. K. Lam, and G. M. Lee. 2002. Voluntary disclosure by state-owned enterprises. Journal of International Financial Management and Accounting 126152.

Firth, M. A. 1979. The impact of size, stock market listing and auditors on voluntary disclosure in corporate annual reports. Accounting and Business Research (Autumn): 273-280.

Frost, C. A. 1997. Disclosure policy choices of UK firms receiving modified audit reports. Journal of Accounting and Economics 23: 163-187.

Gray, S. J., G. K. Meek, and C. B. Robert. 1995. International capital market pressures and voluntary mannual report disclosures by U.S. and U.K. multinationals. Journal of International Financial Management and Accounting 6 (1): 43-68.

Healy, P. M., K. G. Palepu, and A. Sweeney. 1995. Do firms benefits from expanded voluntary disclosure? MIT Sloan School of Management.

Herwidayatmo. 2000. The role of disclosure in strengthening corporate governance and accountibility. Paper. Presented at the Second Asian Roundtable on Corporate Governance.

Hooks, J., D, C., and H. Davey. 2001. Accountability through annual reporting by New Zealand electricity retail and distribution companies. Paper. Presented at the Third Asian Pacific Interdisciplinary Research in Accounting Conference, Adelaide, Australia.

Hossain, M., M. H. B. Perera, and A. R. Rahman. 1995. Voluntary disclosure in the annual reports of New Zealand companies. Journal of International Financial Management and Accounting 6 (1): 69-87.

Husnan, S. 2001. Indonesia. Asian Development Bank.

IIA/SFAS (Statement of Financial Accounting Standards). Jakarta, Indonesia.

Jakarta Stock Exchange and Surabaya Stock Exchange. Indonesian Stock Exchange Regulations. 
Wijantini-Voluntary Disclosure in the Annual Reports...

Jensen, M. C., and W. H. Meckling. 1976. Theory of the firm: Managerial behavior, agency costs and ownership structure. Journal of Financial Economics.

King, R., G. Pownall, and G. Waymire. 1990. Expectations adjustments via timely earnings forecast disclosure: Review, synthesis and suggestions for future research. Journal of Accounting Literature 9: 111-144.

Lang, M. H., and R. J. Lundholm. 1993. Cross sectional determinants of analyst ratings of corporate disclosures. Journal of Accounting Research 31 (2)(Autumn): 246-272.

Lasfer, M. A., P. S. Sudarsanam, and R. J. Taffler. 1996. Financial distress, asset sales and lender monitoring. Financial Management 25 (3) (Autumn): 57-66.

Meek, G. K., C. B. Robert, and S. J. Gray. 1995. Factors influencing voluntary annual report disclosures by U.S., U.K. and Continental European Multinational Corporations. Journal of International Business Studies (Third Quarter): 555 - 572.

Obata, S. 2001. Pyramid groups, financial distress and investor protection. Working Paper (November).

O'Flaherty, J. 1984. Going Public: The Entrepreneur's Guide. New York: John Wileyand Sons.

Opler, T. C., and S. Titman. 1994. Financial distress and corporate performance. Journal of Finance 49 (3): 1015-1040.

Patton, J., and I. Zelenka. 1997. An empirical analysis of the determinants of the extent of joint stock companies in the Czech Republic. The European Accounting Review 6: 605-626.

Rajan, R., and A. Winton. 1995. Covenants and collateral as incentives to monitor. Journal of Finance 50: 1113-1146.

Ramos, R. 1999. Financial restructuring scorecard. Goldman Sachs. Hong Kong.

Stiglitz, J. E., and A. Weiss. 1981. Credit rationing in markets with imperfect information. American Economic Review 71: 393-410.

Susanto, D. 1992. An empirical investigation of the extent of corporate disclosure in annual reports of companies listed on the Jakarta Stock Exchange. Unpublished Ph.D. Thesis. University of Arkansas.

Thomas, R. L. 1997. Modern Econometrics: An Introduction: Prentice Hall.

Trueman, B. 1986. Why do managers voluntarily release earnings forecasts? Journal of Accounting and Economics 8: 53-71.

Utama, S. 2003. Corporate governance, disclosure and its evidence in Indonesia. Usahawan 5: $11-15$.

Webb, L. M. H. 2002. Strategic use of disclosure policy in distressed firms. Unpublished PhD Thesis. Texas A and M.

Whitaker, R. B. 1999. The early stages of financial Distress. Journal of Economics and Finance 23 (2) (Summer): 123-133.

Wruck, K. H. 1990. Financial distress, reorganization and organizational efficiency. Journal of Financial Economics 27 (October): 419-444. 